\title{
A Comparative Study on Cyber Ethics, Religious Awareness and Satisfaction in Using Facebook for Social Networking
}

\author{
Che Noraini Hashim
}

Email: cnoraini@gmail.com

\section{Sharifah Sariah Syed Hassan}

Email: sariah1199@yahoo.com

Doi:10.5901/ajis.2013.v2n3p419

\begin{abstract}
Throughout the internet's evolution, debates on cyber ethics had raised concerns within the educational system. New ethical dilemmas turned to emerge out of compounding facebook communication among users. Ethical behaviour involving computer networking has immense power in promoting not only valuable academic networking, but could be shifted for self-fulfillment and even for evil ends. The issue of moral behavior involving computer networking is defined as cyber ethics. Arief, Dana, and Aniati (2011) synthesized the definition of ethics as right or wrong behavior based on respect. Studies relating to moral values further, systemize, defend and recommend concepts of right and wrong behavior. Despite the arguments of ethics as guidelines of social behavior and reflections of morality, Kaddu (2007) conceptualizes ethics as a set of values that lead to happiness, success and fulfillment. Guarded with some religious awareness, will cyber ethics makes a difference across boundaries and could religious values guide usage satisfaction during Facebook communication? This paper aims to clear doubts on cyber ethics using samples drawn from Facebook social communication among Malaysian and Indonesian undergraduates. It shall identify patterns of relationship between cyber ethics, religious awareness and usage satisfaction. The paper also discusses some implications of these relationships to reveal the level of satisfaction in using Facebook.Questionnaires were distributed to selected universities from Indonesia and Malaysia; 200 undergraduates responded. Correlation, independent $t$-test and multiple regression analysis were conducted on the data set. The measurement level such as honesty, truthfulness and respect were applied. The study revealed that cyber ethics across boundaries was significantly different. There is a significant relationship between religious awareness and cyber ethics. Facebook communication in the two countries was used by respondents with some religious awareness. This relationship has significant influence on the level of satisfaction while communicating in social networking sites.
\end{abstract}

Keywords: Cyber ethics, Facebook, Social network, religious awareness

\section{Introduction}

A social behavior in real life can be similar or different to a social behavior when people communicate on the Internet. The issue of moral behavior involving computer networking is defined as cyber ethics. Arief, Dana, and Aniati (2011) synthesized the definition of ethics as right and wrong behavior based on respect. Studies relating to moral values, systemize, defend and recommend concepts of right and wrong behavior. Despite the arguments of ethics as guidelines of social behavior and reflections of morality, Kaddu (2007) conceptualizes ethics as a set of values that lead to happiness, success and fulfillment. When adolescents are communicating online, they sometimes believe that being anonymous is secured since others could not notice and identify their identities. However, some might only be accepted as friends when they are known in the group. Thus, concealing personal details, sharing information and become part of the social norm in the cyber world will affect the way others accept the friendship. The repercussion from the social act in the cyber world will also impact on the actions in the real world. Thus, the need to carry out a research on cyber ethics must also address the issue of religious awareness, satisfaction and life goal. This empirical study is hardly materialized due to insufficient literature of cyber ethics and religious practices that influence information disclosure in social network sites. The existing research in social networking were more focused on factors affecting information disclosure (Stuzman, Capra and Thompson, 2011), boundaries in privacy management (Petronio and Durham, 2008); motivation and consequences (Waters, \& Ackerman, 2011); The present study therefore will contribute to the literature of privacy disclosure in social network where information is dwelled from students' experience and knowledge of cyber ethics and 
religious awareness.

Fieser's (2009) divided ethics into three principles namely; meta-ethics, normative ethics and applied ethics. Metaethics involves the investigation of the roots of the ethical principles indicating where it comes from and what it means. This concept focuses on the truths universally accepted, with the will of God and reasoning towards ethical judgment. The second concept relates to normative ethics which is more practical as it relates to moral standards that drives people to right or wrong conducts. Thus, it allows people to think further on the impact of their actions to others. Fieser has further classified the normative ethics as driven by three theories which are virtue theories, duty theories, and consequentialist theories. The last concept is the applied ethics which is classified as values adapted to the needs of the environment. It can be explained from the perspectives of professional needs and groups.

\section{Objectives}

Based on the ethical behavior from facebook communication via internet, this paper analysed the extent of cyber ethics practices from the religious awareness and universal academic perspectives. It identified the relationships between cyber ethics (of meta-ethics) and religious awareness and discussed whether or not such relationships had induced students at higher learning institutions to think of the consequences from their good ethical behaviours or from their cyber misconducts during Facebook conversations. The paper focuses on the following three research questions:

\subsection{Research Question 1}

Do patterns of cyber ethics practices and religious awareness among Indonesian and Malaysian University undergraduates differ when communicating in facebook (social network sites?

\subsection{Research Question 2}

Do cyber ethics and religious awareness have significant relationship?

\subsection{Research Question 3}

To what extent do cyber ethics and religious awareness affect satisfaction in using social network sites?

The paper is set to answer the following hypotheses, namely:

$\mathrm{H}_{1}$ : There exists a significant difference between Indonesian and Malaysian university undergraduates in their practices of cyber ethics and religious awareness;

$\mathrm{H}_{2}$ : There exists a significant relationship between cyber ethics and religious awareness;

$\mathrm{H}_{3}$ : Cyber ethics and religious awareness has significant influence on the level of satisfaction while communicating in social networking.

\section{Research Design and methodology}

This research utilized self constructed survey which focused on questions relating to cyber ethics, religious awareness and satisfaction. The construct of cyber ethics is measured from 'non emotional in writing', 'reply posting in positive manner', 'appropriate use sharing information' and 'acknowledge other author's writing or posting'. Religious awareness is measured from 'the conscious of consequences', 'God consciousness', 'consideration of sensitivity of other religions', 'priority of religious duties' and 'avoiding values against religion'. Satisfaction in using social networks to communicate includes enjoyment, satisfaction, and high self concept. All items (38 questions) were reliable with Cronbach's alpha of 0.78 . The 5 -Likert scale questionnaire was used to measure strongly agree (5) to strongly disagree (1) with undecided is represented by 3. Detailed items are given in Table 2.0. The research was carried out in one Malaysian Government University and a selected Indonesian University. Both Universities are religiously oriented with the vision is to uphold the values of Islam in curriculum implementation and to prepare students in the working environment. The respondents were selected based on the convenient sampling where students were available during the survey in one of the faculties permitted by the Dean. 100 questionnaires were distributed to each university where only 176 responded completely to the data while 24 questionnaires had been discarded due to missing data. The data was analyzed to address the formulated hypothesis for each research question. 


\section{Results and Discussion}

The distribution of respondents is given in Table 1.0. The research involved 90 students from Malaysia (27 males and 63 females) and 86 students from Indonesia (44 males and 42 females).

Table 1.0: Distribution of respondents

\begin{tabular}{|c|c|c|c|c|}
\hline \multicolumn{2}{|c|}{} & \multicolumn{2}{c|}{ Country } & \multirow{2}{*}{ Total } \\
\cline { 3 - 5 } \multicolumn{2}{|c|}{ Gender } & Malaysia & Gontor, Indonesia & \\
\cline { 2 - 5 } & female & 27 & 44 & 71 \\
\hline \multicolumn{2}{|c|}{ Total } & 63 & 42 & 105 \\
\hline
\end{tabular}

The descriptive statistics with mean and standard deviation are given in Table 2.0. All the items for both groups (Malaysia and Indonesia) scored above the average point (>3.0) where the mean scores ranged from 4.1080 I (always consider another person's faith before I write on SNSs) to 4.6761(Religion is an important facet in my everyday life).

Table 2.0:Descriptive statistics for religious awareness

\begin{tabular}{|c|c|c|}
\hline & Mean & Std dev. \\
\hline I am always careful not to hurt people's feeling when posting information on SNSs because it is against my religion & 4.2330 & .86668 \\
\hline I am aware that God is always watching whatever I do on SNSs & 4.6648 & .67283 \\
\hline I always consider another person's faith before I write on SNSs & 4.1080 & .91636 \\
\hline I can postpone my activities on SNSs whenever I have a religion duties & 4.2784 & .84636 \\
\hline I am aware that exposing my personal details to others on SNSs is against my religion & 4.4489 & .91195 \\
\hline I always avoid backstabbing people through any means including SNSs because my religion discourages such act & 4.3580 & .81573 \\
\hline My religion is against exposing privacy other people on SNSs & 4.3352 & 1.0119 \\
\hline I always avoid teasing on SNSs as it is against my religion teachings & 4.1591 & .89297 \\
\hline Luring others for dubious activities on SNSs highly detested by me as it is against my religion teaching & 4.2841 & .98502 \\
\hline It is not good to cheat/con people on SNSs because it is against my religion practice & 4.3920 & .80693 \\
\hline Religion is an important facet in my everyday life, & 4.6761 & 1.59780 \\
\hline My practice of honesty is in accordance with the teaching of my religion & 4.2614 & 4.77082 \\
\hline I always respect my privacy and privacy of others on SNSs as preached by my religion & 4.4830 & .77809 \\
\hline
\end{tabular}

Source : Questionnaire survey 2013

In Table 3.0, the highest mean score is 4.2670 (It is unethical to publicize others privacy to strangers on SNSs). The lowest is revealed from 'I usually avoid using smiley icons as this sometimes do not transmit very well on SNSs' (2.7330). Despite the emphasis given to smiley as one of the ethics needs to be addressed, both Malaysian and Indonesian students do not seem to agree on 'the practice in writing smiley on SNSs'.

Table 3.0: Cyber ethics in writing and posting in SNSS

\begin{tabular}{|l|c|c|}
\hline & Mean & Std. Deviation \\
\hline If I am too emotional at the time of writing online, I store, review and send it later & 3.6705 & 1.17810 \\
\hline It is good to use appropriate language on SNSs & 4.1591 & .96079 \\
\hline I avoid writing in CAPS as this is considered yelling or screaming to others & 3.5852 & 1.23455 \\
\hline I usually avoid using smiley icons as this sometimes do not transmit very well on SNSs & 2.7330 & 1.22463 \\
\hline Whenever personal information is posted to my SNSs account I reply directly to the senders' wall & 3.1420 & 1.32546 \\
\hline Forwarding chain letters on SNSs is very annoying & 3.5682 & 1.20755 \\
\hline I am very selective in forwarding jokes on SNSs & 3.7727 & 1.07147 \\
\hline I am very selective in forwarding messages on SNSs & 3.8807 & 1.00426 \\
\hline It is polite to acknowledge important Messages on SNSs & 3.6420 & 1.18671 \\
\hline It is unethical to publicize others privacy to strangers on SNSs & 4.2670 & .96347 \\
\hline It is unethical to send any link I have not examined & 4.1136 & 1.00208 \\
\hline
\end{tabular}




\begin{tabular}{|l|l|l|}
\hline It is unethical to use other images, website content without their permission & 3.9659 & 1.08442 \\
\hline I clearly identify the authors of the work that is not mine on SNSs & 3.4261 & 1.11877 \\
\hline It is unethical to add informationon on SNSs and give impression that they are mine & 3.8636 & 1.11798 \\
\hline
\end{tabular}

Source : Questionnaire survey 2013

The following discussion is based on the hypotheses:

$\mathrm{H} 1$ : There is significant difference between Indonesian and Malaysian University students in their awareness of cyber ethics and religious awareness.

To address this hypothesis, the total mean score of cyber ethics was computed for both countries. Based on the visual inspection of data in Table 4.0, showed that Malaysians have chosen higher score in religious awareness $(\bar{x}$ $=4.4060$ ) and cyber ethics $(\bar{x}=3.8008)$ as compared to students from Indonesia (religious awareness $(\bar{x}=4.3122)$ and cyber ethics $(\bar{x}=3.5930)$. Independent t-test was used to confirm the significant difference, see Table 4.0. It seemed that only cyber ethics had shown a significant difference, across the two countries $(p<0.05)$.

Table 4.0: Total mean comparison across countries

\begin{tabular}{|c|c|c|c|c|}
\hline & Country & $\mathrm{N}$ & Mean & Std. Deviation \\
\hline Religious & Malaysia & 90 & 4.4060 & .58116 \\
\cline { 2 - 4 } awareness & Indonesia & 86 & 4.3122 & .54064 \\
\hline \multirow{2}{*}{ Cyber ethics } & Malaysia & 90 & 3.8008 & .61225 \\
\cline { 2 - 5 } & Indonesia & 86 & 3.5930 & .65585 \\
\hline
\end{tabular}

Source : Questionnaire survey 2013

Table 4.0: Independent t-test for mean comparison across groups

It is worth noting here that Malaysian students hah shown greater awareness and practice on the cyber ethics as compared to their Indonesian counterparts. This could be due to the wide usage of social network and knowledge sharing, privacy management and information disclosure. This finding support and suggests that cyber citizens can be produced through educating students for cyber literacy in the classroom (Berson and Berson, 2003).

$\mathrm{H} 2$ : There is a significant relationship between cyber ethics and religious awareness

A correlation matrix is displayed in Table 5.0 showed significant relationship between the two variables ( religious awareness and cyber ethics) with $\underline{\mathrm{p}}<0.005$ ( $\mathrm{p}=0.000)$ with ( $\mathrm{r}=.474$ Pearson correlation coefficient).

Table 5.0: Correlation between religious awareness and cyber ethics

\begin{tabular}{|c|c|c|c|}
\hline \multicolumn{2}{|c|}{} & Religious & Cyber ethics \\
\hline \multirow{2}{*}{ Religious } & Pearson Correlation & 1 & $.474^{* *}$ \\
\cline { 2 - 4 } & Sig. (2-tailed) & & .000 \\
\hline \multirow{2}{*}{ Cyber ethics } & Pearson Correlation & $.474^{* *}$ & 1 \\
\cline { 2 - 4 } & Sig. (2-tailed) & .000 & \\
\hline${ }^{* *}$. Correlation is significant at the 0.01 level (2-tailed). \\
\hline
\end{tabular}

Source : Questionnaire survey 2013

This finding has confirmed Fieser's (2009) concept of meta-cyber ethics where the goal of action is based on the truths universally accepted, with the will of God and reasoning towards ethical judgment.

$\mathrm{H} 3$ :Cyber ethics and religious awareness influence significantly on their satisfaction in communicating on social networking sites.

For this hypothesis, multiple regression analysis was used to indicate significant influence of independent variables (cyber ethics and religious awareness) on dependent variable (satisfaction). It has been found that cyber ethics practice has significantly influenced the level of satisfaction in using social network sites. Religious awareness does not play significant role in satisfying communication and building relationships online. The model is explained by $11.1 \%$ with 
ANOVA (analysis of variance) results showed significant level of confidence $(p<0.000)$. The feeling of God consciousness, awareness of consequences and impact on others and values of honesty and respect (religious) do not significantly influenced the enjoyment, happiness, positive self concept and communication fulfillment (satisfaction). Despite Islam as religion that moulds the way of life, it is not detected to be the factor in the online communication.

Table 6.0: Multiple regression analysis

\begin{tabular}{|c|c|c|c|c|c|}
\hline \multirow[b]{2}{*}{ Model } & \multicolumn{2}{|c|}{ Unstandardized Coefficients } & \multirow{2}{*}{$\begin{array}{c}\text { Standardized Coefficients } \\
\text { Beta }\end{array}$} & \multirow[b]{2}{*}{$\mathrm{t}$} & \multirow[b]{2}{*}{ Sig. } \\
\hline & $\mathrm{B}$ & Std. Error & & & \\
\hline (Constant) & 2.115 & .434 & & 4.876 & .000 \\
\hline 1 religious awareness & -.010 & .107 & -.008 & -.095 & .925 \\
\hline Cyber ethics practice & .368 & .087 & .337 & 4.216 & .000 \\
\hline
\end{tabular}

Source : Questionnaire survey 2013

\section{Conclusion and Recommendation}

This study seeks to address the three research questions where three hypotheses were tested. It was found that only cyber ethics showed a significant difference across the two countries. The results also showed that there exists a significant relationship between cyber ethics practice and religious awareness. When students' Religious awareness increase they will show commitment in cyber ethics. The model of satisfaction on cyber ethics and religious awareness had indicated that only cyber ethics practice had significantly influenced the level of satisfaction in using SNSs. Thus, further research needs to be carried out with wider coverage and robust data and sampling from different countries, regions, religious practices, ethnicities and age groups.

\section{References}

Arief Ramadhan, Dana Indra Sensuse, Aniati Murni Arymurthy e-Government Ethics : a Synergy of Computer Ethics, Information Ethics, and Cyber Ethics (JACSA) International Journal of Advanced Computer Science and Applications, Vol. 2, No. 8, 2011

Berson I. R. \&. Berson, M. J (2003). Digital Literacy for Cybersafety, Digital Awareness, and Media Literacy. Social Education, Vol.67 (3), 64-68.

Fieser, J. (2009). Ethics, Internet Encyclopedia of Philosophy, A Peer-Reviewed Academic Resources. [Online]. Available: http://www.iep.utm.edu/ethics/

Kaddu, S. B. (2007). Information Ethics: a student's perspective. International Review of Information Ethics, Vol. 7

Stutzman,F., Capra,R., \& Thompson,J. (2011). Factors mediating disclosure in social network sites. Computers in Human Behavior 27 (2011) $590-598$

Petronio, S., \& Durham, W. T. (2008). Communication privacy management. In L. A. Baxter \& D. O. Braithwaite (Eds.), Engaging theories in interpersonal communication: Multiple Perspectives (pp. 309-322). Thousand Oaks, CA: Sage.

Westin, A. (1967). Privacy and Freedom, New York: Atheneum

Waters, S., \& Ackerman, J. (2011). Exploring Privacy Management on Facebook: Motivations and Perceived Consequences of Voluntary Disclosure. Journal of Computer-Mediated Communication, 17 (1), 101-115. 
